\title{
Kajian Naratif Teologi Allah Menyesal Berdasarkan 1 Samuel 15:1-35 Dan Implikasinya Dalam Kehidupan Orang Percaya
}

\author{
Mershy Christiana Lauled, Peniel C. D. Maiaweng
}

\begin{abstract}
Abstrak
Pemahaman tentang makna Allah menyesal seringkali masih membingungkan bagi orang percaya, apalagi bagi orang yang tidak percaya. Pernyataan Allah menyesal tampaknya menunjukkan keterbatasan Allah, seakan-akan Allah tidak Mahatahu dan tidak berdaulat sehingga Ia harus menyesali keputusan-Nya yang telah diambil sebelumnya. Hal ini tampak dalam peristiwa yang melibatkan Saul sebagai raja Israel yang tercatat pada teks 1 Samuel 15:1-35. Allah menyesal telah menjadikan Saul raja, sebab dia telah berbalik dari Tuhan dan tidak melaksanakan firman-Nya. Apakah Allah telah salah memilih dan mengangkat Saul menjadi raja Israel, sehingga Ia harus mengubah keputusan-Nya itu? Apakah penyesalan Allah sama dengan penyesalan manusia? Apakah sesungguhnya makna Allah menyesal dalam konteks ini? Karena itulah karya ilmiah ini bertujuan untuk menemukan makna sesungguhnya dari pernyataan Allah menyesal. Adapun metode penelitian yang digunakan adalah metode penelitian kualitatif dengan penalaran induktif. Tahapan dalam penelitian ini adalah pada bab 2 melakukan analisis isi Alkitab (introduksi), antara lain gambaran umum, penulis dan tanggal penulisan, tujuan, keunikan dan garis besar kitab 1 Samuel. Pada bab 3 dilakukan analisis kesusastraan, analisis makna kata dan tata bahasa, serta analisis narasi terhadap teks 1 Samuel 15:1-35 berdasarkan prinsip-prinsip hermeneutik untuk merumuskan berbagai kesimpulan tentang teks 1 Samuel 15:1-35 serta implikasinya dalam kehidupan orang percaya. Berdasarkan hasil penelitian maka dapat ditarik kesimpulan bahwa Allah menyesal tidak boleh dipahami dalam pengertian yang sama dengan manusia menyesal. Allah menyesal adalah Allah yang menyatakan perubahan sikap dan tindakan yang telah diketahui-Nya sebelumnya sesuai dengan tanggapan manusia terhadap-Nya, sehingga Allah yang menyesal adalah Allah yang menuntut ketaatan umat-Nya; Allah yang tidak segan untuk membatalkan berkat dan memastikan hukuman bagi umat-Nya yang melakukan pelanggaran.
\end{abstract}

Kata Kunci: Allah, Saul, Samuel, menyesal, taat, berkat, hukuman.

\section{Pendahuluan}

\section{Latar Belakang Masalah}

Pengenalan akan Allah merupakan salah satu pokok penting dalam pengajaran Perjanjian Lama. Alasannya adalah karena tidak adanya pengenalan akan Allah merupakan sumber penyebab ketidaksetiaan seseorang kepada-Nya. Hal ini terbukti dalam kehidupan 
Israel sebagai umat Allah. Segera setelah bangkit generasi baru yang tidak mengenal dan mengalami kuasa Allah dalam pembebasan Israel dari Mesir, mereka melakukan apa yang jahat di mata Tuhan dan meninggalkan Tuhan dengan beribadah kepada para Baal (Hak. 2:10-11). Sampai kepada pemberitaan para nabi menyatakan bahwa ketiadaan pengenalan akan Allah menjadi sumber malapetaka dan kehancuran (lih. Hos. 4:6a; Yer. 2:8; 4:22).

Pengenalan seseorang akan Allah berkaitan langsung dengan pemahaman dan pandangan orang itu tentang Allah dan itu menentukan sikap hidupnya. Menurut Erickson, "Pandangan seseorang tentang Allah menentukan corak gaya pelayanan dan falsafah hidup seseorang." 1 Namun persoalannya adalah bukan hal mudah untuk memahami Allah. Memang benar bahwa seseorang dimungkinkan untuk mengenal Allah, tetapi itu hanya sejauh penyataan diri Allah sendiri. Allah sendiri adalah Sumber pengetahuan tentang Dia. ${ }^{2}$ Padahal penyataan diri Allah terbatas, demikian juga kemampuan manusia untuk memahami penyataan diri Allah itu sangat terbatas. Erickson mengatakan,

Sekalipun penyataan diri Allah itu pastilah konsisten dan tepat sesuai dengan kodratNya, namun penyataan diri itu tidak merupakan penyataan yang lengkap. Lagi pula, kita juga tidak mengetahui atau mengerti sepenuhnya apa yang telah dinyatakan Allah tentang diri-Nya. Dengan demikian, ada, dan senantiasa akan ada, unsur rahasia yang tidak dapat kita ketahui tentang Allah. ${ }^{3}$

Akibatnya seringkali terjadi kebingungan dalam memahami penyataan Allah, bahkan di kalangan orang Kristen sendiri. Salah satu contoh adalah pernyataan tentang Allah "menyesal" yang banyak terdapat dalam Perjanjian Lama (lih. Kej. 6:6-7; Kel. 32:14; 1 Sam. 15:11, 35; 2 Sam. 24:16; 1 Taw. 21:15; Yer. 18:8, 10; 26:3; Am. 7:3, 6; Yun. 3:10). Pernyataan Allah "menyesal" cukup membingungkan. Apakah Allah dapat menyesal sama seperti manusia menyesal? Apakah Allah dalam kemahatahuan-Nya bisa merasakan penyesalan? Berdasarkan penelitian Bambang Wiku Hermanto, ditemukan bahwa responden ${ }^{4}$ cenderung untuk setuju penyesalan Allah sama dengan penyesalan manusia. ${ }^{5}$

Konsekuensinya adalah muncul pemahaman bahwa Allah tidak konsisten dalam keputusan-Nya atau Allah dapat berubah pikiran dan mengubah keputusan-Nya. Konsekuensi lainnya yang dapat muncul adalah tuduhan bahwa Allah yang menyatakan diri dalam Alkitab adalah Allah yang tidak Mahatahu dan tidak berdaulat. Seakan-akan Allah bisa saja salah dalam mengambil keputusan dan karena itu Ia akan menyesali keputusan-Nya sendiri. Menurut Bambang Wiku Hermanto, hal ini dapat menjadi peluang munculnya tuduhan bahwa Alkitab mengandung kesalahan, bahkan meragukan Allah yang absolut. ${ }^{6}$

\footnotetext{
${ }^{1}$ Millard J. Erickson, Teologi Kristen: Volume Satu (Malang: Gandum Mas, 2004), 421.

${ }^{2}$ Charles C. Ryrie, Teologi Dasar 1 (Yogyakarta: ANDI, 2012), 34.

${ }^{3}$ Erickson, 426.

${ }^{4}$ Responden dari penelitian ini adalah kalangan STT, pengerja gereja, aktivis atau pengurus gereja, dan anggota gereja.

5 Bambang Wiku Hermanto, "Pengertian Orang Percaya Tentang Ungkapan "Allah Menyesal"," Jurnal Simpson 2, No. 1 (Juni 2015):27, diakses 12 Februari 2018, http://journal.sttsimpson.ac.id/index.php/ Js/article/viewFile/18/17.

${ }^{6}$ Bambang Wiku Hermanto, "Kajian dan Uraian Apologetis Teologis Terhadap Ungkapan "Allah Menyesal" Dalam Alkitab," Evangelikal: Jurnal Teologi Injili dan Pembinaan Warga Jemaat 1, No. 1 (Januari 2017):29, diakses 12 Februari 2018, http://journal.sttsimpson.ac.id/index.php/EJTI
} 
Namun benarkah penyesalan Allah sama dengan penyesalan yang dialami oleh manusia dengan pengertian Allah dapat berubah? Pertanyaan ini telah menjadi sumber perdebatan secara teologis di antara para ahli. Menurut Charles C. Ryrie, penyesalan Allah sama sekali tidak berarti ada perubahan dalam diri Allah sendiri, sebab jika ada perubahan, maka itu berarti: kalau Ia tidak tetap tentu Ia tidak berdaulat atau keduanya. ${ }^{7}$ Sedangkan menurut Donald C. Stamps, Allah menyesal menunjukkan bahwa Allah dapat mengubah perasaan, sikap, tindakan dan pikiran-Nya sesuai dengan tanggapan yang berubah terhadap kehendak-Nya. ${ }^{8}$

Masalah di atas tampak pada salah satu teks yang menyatakan Allah menyesal, yaitu pada 1 Samuel 15:1-35. Di dalam 1 Samuel 15:11, Tuhan secara jelas menyatakan kepada Samuel lewat firman-Nya, bahwa Ia menyesal telah menjadikan Saul raja. Kemudian diperkuat lagi oleh narator dalam ayat ke 35 bahwa Tuhan menyesal karena Ia menjadikan Saul raja atas Israel. Kedua pernyataan ini tampaknya menunjukkan bahwa Allah bukanlah Allah yang Mahatahu, tidak berdaulat dan tidak konsisten dalam keputusan-Nya sendiri. Allah sendiri yang memilih dan mengangkat Saul sebagai raja Israel, namun Ia sendiri yang menyesali keputusan-Nya itu dan mengubah keputusan-Nya tentang status Saul, yaitu menolak Saul sebagai raja Israel.

Masalahnya adalah apakah ketika Allah memilih dan mengangkat Saul sebagai raja Israel, Allah tidak mengetahui bahwa kelak Saul akan berubah setia kepada-Nya dengan tidak menaati perintah-Nya? Apakah Allah telah salah memilih dan mengangkat Saul sebagai raja Israel sehingga Ia harus mengubah keputusan-Nya itu? Apakah Allah menyesal sama pengertiannya dengan manusia menyesal? Apakah sesungguhnya yang hendak dinyatakan Allah melalui pernyataan-Nya bahwa Ia menyesal telah menjadikan Saul raja atas Israel? Kemudian dalam ayat 29 muncul pernyataan Samuel bahwa Allah tidak tahu menyesal, sebab Ia bukan manusia yang harus menyesal. Bagaimana Allah yang menyesal juga sekaligus Allah yang tidak tahu menyesal? Pertanyaan-pertanyaan penafsiran tentang sikap dan tindakan Allah ini perlu dikaji secara cermat agar tidak menghasilkan jawaban yang bertentangan dengan karakter Allah yang sesungguhnya dan tidak sesuai dengan maksud Allah yang sebenarnya.

Terhadap masalah penafsiran seperti ini, David Tsumura menyatakan bahwa makna atau arti suatu kata atau frasa ditentukan berdasarkan konteks di mana kata atau frasa itu muncul dan siapa yang menggunakannya. ${ }^{9}$ Sehingga makna penyataan Allah menyesal dapat ditemukan dengan memperhatikan konteks peristiwa di mana pernyataan itu muncul. Sebagai contoh, penyataan Allah menyesal dalam Kej. 6:6 yang merupakan perkataan Allah sendiri, maknanya secara konteks disimpulkan oleh Yetris Elbaar sebagai berikut:

Allah sangat berdukacita ketika menyaksikan manusia dengan kebobrokan moral dan tenggelam di dalamnya, Allah mengetahui setiap rancangan-Nya bagi manusia, sehingga melalui hal itu Allah mengungkapkan bahwa Ia menyesal bukan karena Ia tidak mengetahui apa yang akan terjadi dalam kehidupan manusia, tetapi Ia menyesal

\footnotetext{
${ }^{7}$ Ryrie, 53.

${ }^{8}$ Donald C. Stamps, ed., Alkitab Penuntun Hidup Berkelimpahan (Malang: Gandum Mas, 2012), 16.

${ }^{9}$ David Tsumura, The First Book of Samuel (Grand Rapids, MI: Wm. B. Eerdmans Publishing Co., 2007), 407.
} 
karena manusia tidak mampu menjaga kesinambungan karya kebaikan yang diberikanNya kepada manusia. ${ }^{10}$

Contoh yang lain adalah kasus yang dihadapi Yunus yang marah kepada Allah karena Allah menyesal atas malapetaka yang telah dirancangkan-Nya terhadap Niniwe dan Ia tidak jadi melakukannya, ketika orang-orang Niniwe bertobat. Peniel Maiaweng menyatakan bahwa dalam konteks ini, Allah yang menyesal adalah Allah yang menyerukan anugerah, Allah yang menerima pertobatan, dan itu merupakan suatu pengakuan iman. ${ }^{11}$

Kedua contoh di atas membuktikan bahwa konteks suatu teks sangat menentukan makna suatu kata atau frasa atau ungkapan yang terdapat di dalam teks itu. Lalu apakah makna pernyataan Allah menyesal dalam konteks 1 Samuel 15:1-35? Berdasarkan latar belakang masalah ini, penulis tertarik untuk menganalisis teks 1 Samuel 15:1-35 untuk menemukan suatu penafsiran yang benar terhadap penyataan Allah menyesal dan implikasinya dalam kehidupan orang percaya masa kini.

\section{Pokok Masalah}

Berdasarkan latar belakang masalah, maka pokok masalah dalam penulisan karya ilmiah ini yaitu:

Pertama, apakah makna teologi Allah menyesal berdasarkan 1 Samuel 15:1-35?

Kedua, apakah implikasi praktis dari teologi Allah menyesal berdasarkan 1 Samuel 15:1-35 dalam kehidupan orang percaya?

\section{Tujuan Penelitian}

Adapun tujuan penelitian karya ilmiah ini adalah:

Pertama, untuk mengkaji dan menjelaskan makna teologi Allah menyesal berdasarkan 1 Samuel 15:1-35.

Kedua, untuk menjelaskan implikasi praktis dari teologi Allah menyesal berdasarkan 1 Samuel 15:1-35 dalam kehidupan orang percaya.

\section{Manfaat Penelitian}

Pertama, karya ilmiah ini dapat menjadi bahan bacaan yang menambah wawasan, baik bagi penulis maupun bagi para pembaca.

Kedua, agar pembaca menyadari dan memahami teologi Allah menyesal, serta dapat mengimplikasikannya dalam kehidupan orang percaya.

Ketiga, untuk memenuhi salah satu syarat akademik dalam menyelesaikan program stratum satu (S1) pada Sekolah Tinggi Theologia Jaffray Makassar.

\section{Metode Penelitian}

Metode penelitian dalam penulisan karya ilmiah ini menggunakan metode penelitian kualitatif dengan penalaran induktif. ${ }^{12}$ Adapun tahapan dalam penelitian ini adalah pada bab

\footnotetext{
${ }^{10}$ Yetris Elbaar, Peniel Maiaweng, "Tinjauan Teologis: Allah Menyesal Berdasarkan Perspektif Kitab Kejadian Pasal 6:6-7," Jurnal Jaffray 11, No. 2 (Oktober 2013):124.

${ }^{11}$ Peniel Maiaweng, “'Utuslah Aku': Eksposisi Yunus Pasal 3-4 Tentang Pengutusan Nabi Yunus Berdasarkan Perspektif Allah Menyesal,”Jurnal Jaffray 10, No. 2 (Oktober 2012):20-22.

12 Penalaran induktif adalah suatu kegiatan berpikir yang erat hubungannya dengan penarikan kesimpulan dari kasus-kasus individual (khusus) menjadi kesimpulan yang bersifat umum. Atau dapat juga
} 
2 melakukan analisis isi Alkitab (introduksi), antara lain gambaran umum, penulis dan tanggal penulisan, tujuan, keunikan dan garis besar kitab 1 Samuel. Pada bab 3 dilakukan analisis kesusastraan, analisis makna kata dan tata bahasa, serta analisis narasi terhadap teks 1 Samuel 15:1-35 berdasarkan prinsip-prinsip hermeneutik untuk merumuskan berbagai kesimpulan tentang teks 1 Samuel 15:1-35 serta implikasinya dalam kehidupan orang percaya. Metode penafsiran narasi digunakan karena sesuai dengan genre dari 1 Samuel 15:135, yaitu narasi Perjanjian Lama.

Analisis isi Alkitab (introduksi) dilakukan dengan berfokus pada topik yang berhubungan langsung dengan isi kitab, yaitu penulis, tanggal dan tempat penulisan, tujuan kitab. ${ }^{13}$ Analisis ini bertujuan untuk memahami isi kitab yang akan ditafsir. Analisis kesusastraan dalam penelitian ini tertuju hanya pada penyelidikan tujuan dan struktur kitab, serta ragam sastra. Penyelidikan terhadap tujuan dan struktur kitab adalah penyelidikan yang penting karena keduanya saling mendukung. Penulis kitab memiliki tujuan tertentu dengan tulisannya dan struktur penulisan akan membantu menyingkapkan tujuan itu. Sedangkan penyelidikan ragam sastra dari bagian teks yang akan ditafsir menolong penafsir untuk memilih metode penafsiran yang sesuai, karena ragam sastra yang berbeda perlu ditafsir dengan metode yang berbeda pula. ${ }^{14}$

Penafsiran narasi adalah metode penafsiran yang mengacu kepada analisis terhadap kitab-kitab atau bagian-bagian dari kitab-kitab dalam Alkitab sebagai sebuah kesusastraan yang utuh dengan memfokuskan perhatian pada narator/pencerita, plot/alur dan adegan, kata kunci dan pengulangan, tokoh, atmosfir, sudut pandang, dan pemilihan materi. ${ }^{15}$

\section{Batasan Penelitian}

Mengingat luasnya makna teologi Allah menyesal, maka penulisan karya ilmiah ini dibatasi hanya berfokus pada teologi Allah menyesal berdasarkan 1 Samuel 15:1-35 dan implikasinya dalam kehidupan orang percaya.

\section{Kesimpulan}

Berdasarkan pembahasan dari kajian naratif tentang teologi Allah menyesal berdasarkan 1 Samuel 15:1-35 dan implikasinya dalam kehidupan orang percaya, maka dapat ditarik beberapa kesimpulan sebagai berikut:

Pertama, Allah yang menyesal tidak dapat dipahami dengan pengertian yang sama dengan manusia yang menyesal. Allah menyesal sama sekali tidak menunjukkan keterbatasan Allah dalam pengetahuan sehingga Ia telah mengambil keputusan yang salah

diartikan sebagai kegiatan berpikir yang bertolak dari masalah-masalah nyata dalam suatu konteks ruang dan waktu (lapangan) atau suatu komunitas/populasi kepada kesimpulan yang dapat diterapkan untuk umum (luas); Stevri Indra Lumintang dan Danik Astuti Lumintang, Theologia Penelitian \& Penelitian Theologis (Jakarta: Geneva Insani Indonesia, 2016), 95.

${ }^{13}$ Hasan Sutanto, Hermeneutik: Prinsip dan Metode Penafsiran Alkitab (Malang: Literatur SAAT, 2007), 271.

${ }^{14}$ Sutanto, 296.

${ }^{15}$ Peniel Maiaweng, Penafsiran Narasi Perjanjian Lama (Makassar: STT Jaffray, 2014), 1. Peniel Maiaweng mengutip Janice Capel Anderson and Stephen Moore, Mark \& Method: New Approacher in Biblical Studies (Chattanooga: Precept Ministries, 1992), 165; Andreas B. Subagyo, Pengantar Riset Kuantitatif \& Kualitatif (Bandung: Kalam Hidup, 2004), 132-133; Walter Kaiser, Jr., Berkhotbah dan Mengajar dari Perjanjian Lama (Bandung: Kalam Hidup, 2009), 81-82. 
dan pada akhirnya harus menyesalinya. Allah menyesal juga tidak menunjukkan bahwa Allah tidak konsisten dalam kehendak, rencana dan tujuan-Nya. Allah menyesal adalah Allah yang menyatakan perubahan sikap dan tindakan yang telah diketahui-Nya sebelumnya sesuai dengan tanggapan manusia terhadap-Nya.

Kedua, Allah menyesal mengungkapkan salah satu sifat Allah, yaitu ketidakberubahan Allah. Sifat tidak berubah adalah salah satu sifat yang menyatakan kebesaran Allah. Allah tidak pernah berubah; firman-Nya, baik itu janji berkat maupun ancaman hukuman pasti akan tergenapi, karena itu Ia dapat diandalkan.

Ketiga, berdasarkan pengertian konteks 1 Samuel 15, Allah yang menyesal adalah Allah yang senantiasa menuntut ketaatan dari umat-Nya, Allah yang tidak segan untuk membatalkan berkat yang Dia janjikan tatkala umat-Nya berbalik dari pada-Nya, dan Allah yang pasti memberikan hukuman kepada umat-Nya yang berdosa.

Keempat, implikasi teologis dari Allah menyesal adalah Allah yang membenci dosa; Allah yang menyatakan keadilan-Nya; Allah yang setia dan tidak berubah; dan Allah yang berdaulat.

Kelima, implikasi praktis dari Allah menyesal adalah orang percaya harus hidup dalam kesetiaan dan ketaatan kepada Allah, senantiasa mengakui dosa dan bertobat, teguh dalam iman, dan takut akan Allah.

\section{Kepustakaan}

Baker, D. L., S. M. Siahaan, A. A. Sitompul. Pengantar Bahasa Ibrani. Jakarta: BPK Gunung Mulia, 2009.

Baldwin, Joyce G. 1 and 2 Samuel: An Introduction and Commentary. Nottingham, England: Inter-Varsity Press, 1988.

Boice, James Montgomery. Dasar-Dasar Iman Kristen. Surabaya: Momentum, 2011.

Brill, J. Wesley. Dasar Yang Teguh. Bandung: Kalam Hidup, n.d.

Carson, D. A. Doktrin Yang Sulit Mengenai Kasih Allah. Surabaya: Momentum, 2007.

Chamblin, J. Knox. Paulus dan Diri: Ajaran Rasuli bagi Keutuhan Pribadi. Surabaya: Momentum, 2009.

Chisholm Jr, Robert B. Teach The Text Commentary Series 1 \& 2 Samuel. Grand Rapids, MI: Baker Books, 2013.

Chisholm Jr, Robert B. "Does God Change His Mind?" Bibliotheca Sacra 152 (OctoberDecember 1995):387-399.

Elbaar, Yetris, Peniel Maiaweng. "Tinjauan Teologis: Allah Menyesal Berdasarkan Perspektif Kitab Kejadian Pasal 6:6-7.” Jurnal Jaffray 11, No. 2 (Oktober 2013):114-139.

Erickson, Millard J. Teologi Kristen: Volume Satu. Malang: Gandum Mas, 2004.

Frame, John M. Apologetika Bagi Kemuliaan Allah. Surabaya: Momentum, 2000.

Gaebelein, Frank E. Ed. The Expositor's Bible Commentary Volume 3 (Deuteronomy-2 Samuel). Grand Rapids, Michigan: Zondervan Publishing House, 1992.

Green, Denis. Pembimbing Pada Pengenalan Perjanjian Lama. Malang: Gandum Mas. 
Hermanto, Bambang Wiku. "Kajian dan Uraian Apologetis Teologis Terhadap Ungkapan "Allah Menyesal" Dalam Alkitab." Evangelikal: Jurnal Teologi Injili dan Pembinaan Warga Jemaat 1, No. 1 (Januari 2017):29-48. Diakses 12 Februari 2018. http://journal.sttsimpson.ac.id/index.php/EJTI

Hill, Andrew E. dan John H. Walton. Survei Perjanjian Lama. Malang: Gandum Mas, 2013. Hoo, Woo Ro. Pembacaan Alkitab Secara Menyeluruh. Yogyakarta: ANDI, 2015.

Howard Jr, David M. Kitab-Kitab Sejarah Dalam Perjanjian Lama. Malang: Gandum Mas, 2013. . "Pengertian Orang Percaya Tentang Ungkapan "Allah Menyesal”.” Jurnal Simpson 2, No. 1 (Juni 2015):11-36. Diakses 12 Februari 2018. http://journal.sttsimpson.ac.id/index.php/Js/article/viewFile/18/17.

Johnston, Philip. Pengantar untuk Mengenal Alkitab: Memahami Alkitab berdasarkan Sejarah, Tema, dan Penafsirannya. Bandung: Kalam Hidup, 2011.

Kaiser, Jr., Walter C. Toward Old Testament Ethics. Grand Rapids, Michigan: Zondervan Publishing House, 1983.

Kelley, Page H. Pengantar Tata Bahasa Ibrani Biblikal. Surabaya: Momentum, 2013.

Lasor, W. S., D. A. Hubbard, dan F. W. Bush. Pengantar Perjanjian Lama 1: Taurat dan Sejarah. Jakarta: BPK Gunung Mulia, 2016.

Lumintang, Stevri Indra dan Danik Astuti Lumintang. Theologia Penelitian \& Penelitian Theologis. Jakarta: Geneva Insani Indonesia, 2016.

Maiaweng, Peniel C. D. Penafsiran Narasi Perjanjian Lama. Makassar: Sekolah Tinggi Theologia Jaffray Makassar, 2014.

Maiaweng, Peniel. “'Utuslah Aku': Eksposisi Yunus Pasal 3-4 Tentang Pengutusan Nabi Yunus Berdasarkan Perspektif Allah Menyesal." Jurnal Jaffray 10, No. 2 (Oktober 2012):16-36.

McGee, J. Vernon. Thru the Bible with J. Vernon McGee Volume II (Joshua-Psalms). Nashville, Tennessee: Thomas Nelson Publishers, 1982.

Murray, John. Penggenapan dan Penerapan Penebusan. Surabaya: Momentum, 2010.

Osborne, Grant R. Spiral Hermeneutika: Pengantar Komprehensif bagi Penafsiran Alkitab. Surabaya: Momentum, 2012.

Paterson, Robert M. Tafsir Alkitab Kontekstual-Oikumenis 1 dan 2 Samuel. Jakarta: BPK Gunung Mulia, 2017.

Pfeiffer, Charles F. Everett F. Harrison. The Wycliffe Bible Commentary: Tafsiran Alkitab Wycliffe Volume 1. Malang: Gandum Mas, 2004.

Pink, Arthur W. Kedaulatan Allah. Surabaya: Momentum, 2005.

Piper, John. Kesukaan Allah. Surabaya: Momentum, 2008.

Pratt Jr., Richard L. Ia Berikan Kita Kisah-Nya. Surabaya: Momentum, 2008.

Ryrie, Charles C. Teologi Dasar 1. Yogyakarta: ANDI, 2012.

Scheunemann, Rainer. Pengantar Perjanjian Lama. Abepura: Sekolah Alkitab Malam Gereja Kristen Injili di Tanah Papua, 2004.

Sitompul, A. A., Ulrich Beyer. Metode Penafsiran Alkitab. Jakarta: BPK Gunung Mulia, 1998.

Snoek, I. Sejarah Suci. Jakarta: BPK Gunung Mulia, 1985.

Sutanto, Hasan. Hermeneutik: Prinsip dan Metode Penafsiran Alkitab. Malang: Literatur SAAT, 2007.

Thiessen, Henry C. Teologi Sistematika. Malang: Gandum Mas, 2010. 
Tong, Stephen. Dosa, Keadilan, dan Penghakiman. Surabaya: Momentum, 2006.

Tsumura, David. The First Book of Samuel. Grand Rapids, MI: Wm. B. Eerdmans Publishing Co., 2007. 